\title{
THE ACTIVISM AND SURVIVAL OF THE RIAU-LINGGA 'ULAMA' IN THE DUTCH EAST INDIES COLONIAL ERA (1900-1913)
}

\author{
Mohd Roslan Mohd Nor \\ University of Malaya - Malaysia | m_roslan@um.edu.my \\ Ahmad Dahlan \\ University of Malaya - Malaysia | adahlanbatam@gmail.com
}

\begin{abstract}
The Riau-Lingga Sultanate, previously known as the Sultanate of Johore, covered a large region which included the Riau-Lingga islands, Singapore, some parts of Malaya and some parts of the Sumatera eastern coasts. It was considered a powerful Malay kingdom in the region. However, after the defeat of the Yang Dipertuan Muda Riau Raja Haji in 1784, which was followed by the onesided Anglo-Dutch Treaty in 1824, the sultanate became divided, with only a small part of the region remaining under its rule. This paper attempts to explore the role of 'ulama' in Riau Lingga during the Dutch colonial politics in the region, especially in relation to the discussion of the development of Islam in the early twentieth century Indonesia. It discusses the role and contribution some of the most influential scholars and 'Ulamä' in the sultanate included Raja Ali Tengku Kelana also known as Raja Ali Kelana, Raja Hitam or Raja Khalid Hitam, Raja Abdul Rahman Kecik, Raja Muhammad and the candidate for the Riau-Lingga sultan, Tengku Besar.
\end{abstract}

Keywords: Riau-Lingga Sultanate, Malay archipelago, Johore, Dutch east Indies, 'ulamà', Indonesia and Malay world.

\section{Introduction}

Beginning from the late $19^{\text {th }}$ century until the second decade in the $20^{\text {th }}$ century, the Dutch East Indies central government in Batavia, Indonesia observed that the bordering areas of the British and Dutch 
colonies along the Strait of Malacca and the South China Sea were full of threats towards the stability of the country and the relationship between Batavia and Singapore. According to Eric Taglicozzo, these threats moved as a 'kettle on a slow boil'. ${ }^{1}$

In response to worrying treats from the bordering regions in the north, which included areas in Sumatera, northern Borneo, RiauLingga islands and the South China Sea, the Dutch East Indies government took up a course of actions and political and military policies until the second decade of the $20^{\text {th }}$ century. ${ }^{2}$

The Riau-Lingga government whose region, from 1722 to 1824, covered the Riau-Lingga islands, some districts in the northern Borneo coast, Singapore and some areas in the peninsula which were situated in the 'slow boiling kettle' area, did not escape the notice of the colonial government in Batavia. In other words, the Riau-Lingga government was a politically important region which received serious attention from the Dutch East Indies government at the time. It was considered as a powerful kingdom in the region during that time. ${ }^{3}$ However, the sultanate became divided after the defeat of the Yang Dipertuan Muda Riau Raja Haji in 1784, ${ }^{4}$ which was followed by the one-sided Anglo-Dutch Treaty in $1824^{5}$ that broke up the regions into parts.

Nevertheless, the decisions and political pressure made by Batavia on the Riau-Lingga government finally triggered a serious response from the sultanate's 'Ulamā' (Muslim learned scholars), who acted as sultan's expert consultants of the sultanate. ${ }^{6}$ As a result, the friendship

${ }^{1}$ Eric Tagliacozzo, "Kettle on a Slow Boil: Batavia's Threat Perceptions in the Indies' Outer Islands, 1870-1910”, Journal of Southeast Asian Studies, vol. 31 no. 1 (March 2000), pp. $70-100$.

2 Ibid., p. 70.

${ }^{3}$ Leonard Y. Andaya, Kerajaan Johor 1641-1728 Pembangunan Ekonomi dan Politik (Kuala Lumpur: Dewan Bahasa dan Pustaka, 1987), pp. 370-417.

${ }^{4}$ Regarding the causes and effects of the war between Raja Haji and VOC, refer to Renout Vos, Gentle Janus, merchant prince The VOC and the tightrope of diplomacy in the Malay world, 1740-1800 (Leiden: KITLV Press, 1993).

${ }^{5}$ Regarding the London Treaty and its impact on the Johore government, refer to R.O. Winstedt, A History of Johore (1365-1895) (Kuala Lumpur: MBRAS, 1979), pp. 71-85.

6 Apart from Riau-Lingga, other threatening districts which were later resolved suppressed through military action during this period were Aceh, Jambi and Sunggal in eastern Sumatera. For example, refer to Anthony Reid, Asal Mula Konflik. Aceh Dari Perebutan Pantai Timur Sumatera hingga akhir Kerajaan Aceh abad ke-19 Jakarta: Yayasan 
between the Dutch East Indies government and the Riau-Lingga government, which had been established through a treaty in $1818,{ }^{7}$ slowly reached a boiling point and finally ended in a political conflict. The political conflict finally reached its peak in 1913, when the RiauLingga government was abolished by the Dutch East Indies government. ${ }^{8}$ This paper will examine the roles and responses of the 'Ulama' in the Riau-Lingga government concerning the plans and political decisions made by the Dutch East Indies government on the sultanates which inherited the greatness of the Malaccan and Johore empires. This is to show how discourses of Islam in Indonesia and the Malay world in the early twentieth century were closely interconnected.

\section{Riau-Lingga Sultanate Moved by 'Ulamā',}

Riau-Lingga sultanate was located in the Riau Islands region. It was under the influence of foreign colonization since the Riau war (1782 1784) ${ }^{9}$ in which the Dutch managed to win over Raja Haji Fisabilillah ${ }^{10}$ who led the Riau war. The defeat suffered by Riau was the starting point for the Dutch occupation which offered an agreement to castrate Riau's sovereignty. Since then, Riau-Lingga sultanate suffered the same

Obor Indonesia, 2005); Elsbeth Locher-Scholten. Kesultanan Sumatera dan Negara Kolonial Hubungan Jambi-Batavia (1830-1907) dan Bangkitnya Imperialisme Belanda (Jakarta: KITLV and Banana, 2008); Taufik Abdullah, "Reaksi Terhadap Perluasan Kuasa Kolonial: Jambi Dalam Perbandingan”, in PRISMA, No. 11 (1984), pp. 12-27. Jang A. Muttalib, "Suatu Tinjauan Mengenai Beberepa Gerakan Sosial di Jambi Pada Perempat Pertama abad ke-20", in PRISMA, No. 8 (1980), pp. 26-37. Tengku Lukman Sinar, "Perang Besar dalam Kampung Kecil, Riwayat Perjuangan Rakyat Sunggal", PRISMA, No. 11 (1984), pp. 10-25.

${ }^{7}$ Refer to "Contrac met Johor, Pahan, Riouw, Lingga en Onderh dd. 26 November 1818 (Bt. 15 Maart 1819 No. 34)", in Arsip Nasional Republik Indonesia (ANRI), Surat-Surat Perdjandjian Antara Kesultanan Riau dengan Pemerintahan V.O.C. dan Hindia Belanda 1785-1809 (Jakarta, 1970), pp. 36-53.

8 Virginia Matheson, "Strategies of Survival: The Malay Royal Line of Lingga-Riau", Journal of Southeast Asian Studies, 17, no. 1 (1986): pp. 5-38.

${ }^{9}$ Nordin Hussin, "Trading Networks of Malay Merchants and Traders in the Straits of Melaka from 1780 to 1830”, Asian Journal of Social Science, 40, no. 1 (2012): pp. 51-82.

10 Timothy P. Barnard, "Local heroes and national consciousness: The politics of historiography in Riau", Bijdragen tot de Taal-, Land-en Volkenkunde 4de Afl (1997): pp. 509-526. 
fate with other regions in the Indonesian-Malay Archipelago, such as Aceh ${ }^{11}$ and others which simply means they were colonized.

Dutch colonization began to instill their power by applying a political contract that unilaterally benefited the Dutch and on the other hand harmed the occupied region. In many cases, the Dutch even reneged on the agreement if it did not benefit. As a result, resistance from the nation spread from a place to another.

Similarly, in Riau-Lingga sultanate, the resistance is inevitable. As has happened in many kingdoms of the archipelago, there has been armed resistance against invaders. However, after the physical resistance is deemed ineffective, the resistance then moves in the form of non-physical resistance, so-called the idea and intellectual's resistance. In the case of Riau-Lingga sultanate, the resistance was sparked and carried out by 'Ulama'. ${ }^{12}$

\section{The Riau-Lingga Government and the Colonial political Ties until the Early $20^{\text {th }}$ Century}

The Riau-Lingga and Dutch governments had developed a relationship since the VOC era during the $17^{\text {th }}$ century. However, relationships to form political contracts had begun in 1785 , which were repeatedly renewed between 1820 and $1905 .{ }^{13}$ From that moment, the changes and the expansion of these political contracts slowly and in levels began to limit the political movements of the Riau-Lingga governments on one hand, while expanding the Dutch colonial government's control on them in the other.

This situation became most evident when it became the most important point in the 1824 London Treaty which issued the exclusion of Johore and Pahang from Lingga and Riau into a political contract in 1830. This confirmed the Riau-Lingga government's status as a 'form of mercy' of the Dutch government to the Sultan of Lingga. ${ }^{14}$ However, the most important basis which paved the way to the

\footnotetext{
11 On Aceh occupation, please see Anthony Reid, Asal Mula Konflik, Aceh Dari Perebutan Pantai Timur Sumatera bingga Akbir Kerajaan Aceh Abd ke-19 (Jakarta: Yayasan Obor Indonesia, 2005).

12 Virginia Matheson, "Strategies of Survival: The Malay Royal Line of Lingga-Riau." Journal of Southeast Asian Studies 17, no. 1 (1986): pp. 5-38.

${ }^{13}$ Refer to Arsip Nasional Republik Indonesia (ANRI), Surat-Surat Perdjandjian.

${ }^{14}$ Refer to "Contract met Lingga en Onderboorigh. dd. 29 October 1830", in Arsip Nasional Republik Indonesia (ANRI), Surat-Surat Perdjandjian, p. 70 and p. 72.
} 
substantial accessibility of the Riau-Lingga government directly into the colonial government was a political contract signed by Sultan Sulaiman Badrul Alamsyah, the Yang Dipertuan Muda Riau Rajah Abdullah and the Resident Niuwenhuijzen on December 1st 1857. It was clearly stated in the contract that the Sri Sultan [of Lingga] has a government which is achazah (mempunjai keradjaan itu seqedar djadi suatu achazab) ${ }^{15}$ or in other words only on loan from the Dutch East Indies government.

Since then, or at least since 1868, the Riau Resident who acted as the Dutch East Indies government's representative in Riau-Lingga, began to appoint Assistant Residents in Tanjung Buton to control the Sultan of Riau-Lingga who resided in Daik-Lingga, as well as officers as government representatives in Karimun, Buru Island, and Pengujan and Kijang Mountain on Bintan Island. ${ }^{16}$ The expansion of the Dutch colonial government's control in Riau-Lingga was followed by the establishment of regulations for protocol receptions between the Riau Resident and the Sultan of Riau-Lingga which furthered the former's suzerainty on the latter. ${ }^{17}$

By the early $20^{\text {th }}$ century, the Dutch colonial government began to further its suzerainty on Riau-Lingga through the Resident by repositioning the Sultan of Riau-Lingga from Daik on Lingga Island to Penyengat Island which faced the colonial central government in Tanjung Pinang. A change to the formal arrangement of receptions was made in 1902. This time, it included compulsory regulations for the flags of both governments to be placed together, with the Dutch flag being positioned higher than that of Riau-Lingga. ${ }^{18}$ This regulation was later amplified and confirmed by a political contract in 1905 which was signed by Sultan Abdulrahman, Mu'azamsyah and Resident Wiliam Albert de Kabter without the agreement and signatures of the

15 Please see "Contract met Sultan van Lingga en Onderhoorigh. dd. 291 Desember 1857", in Arsip Nasional Republik Indonesia (ANRI), Surat-Surat Perdjandjian, p. 92. Also refer to Karel E.M. Bongenaar, De ontwikkeling van het relfbestuurrend landschap in Nederlandsch Indie 1855-1942 (Zitphen: Walburg Pers, 2005), p. 634.

${ }^{16}$ For example, refer to "Contract met den Sultan van Lingga-Riouw \& Onderh dd. 30 September 1868" in Arsip Nasional Republik Indonesia (ANRI), Surat-Surat Perdjandjian, p. 183.

${ }_{17}$ ANRI, Besluit Governor General of the Dutch East Indies, No. 8 (16 January 1897).

18 Bijblad No. 5709, besluit Governor General of the Dutch East Indies No. 29 (25 March 1902). Also refer to Bongenaar, De ontwikkeling van het zelfbestuurrend landschap, pp. 635-636. 
governmental scholars in the Rijkraad also known as Imperial Council or Abl al-Mushawwarah (congress consultants) and members of the royal court. ${ }^{19}$

\section{The Roles of the 'Ulama' in Riau-Lingga}

According to Eric Taglicozzo, the greatest potential threat for the Dutch colonial government in the Northern provinces including the bordering areas of the Strait of Malacca where the Riau-Lingga government stood, were the people under the governments which ruled these provinces. Batavia continuously saw what they deemed as 'dark forces' which worked along these borders, which were all very real such as in the Riau-Lingga government. ${ }^{20}$

The presence of the Dutch Empire with their colonial politics increasingly meddled with and narrowed the royal government traditions of provincial power and dignity which have been inherited from generation to generation.

Realising this, the people responded and put up what the Dutch colonial government called a passive fight or lijadelijk verzet against them..$^{21}$ It was a fight which did not make use of physical strength, but could still shake and intimidate the central Dutch colonial governments in Batavia and Bogor. ${ }^{22}$ In fact, the level of tension of the resistance was so high that it drew the uncommon attention of Road van Indie and C. Snouck Hurgronje from the Council of the Indies who acted as the Advisory Borad for Native and Arab Affairs (De Adviseur voor Inlandsche en Arabische Zaken). ${ }^{23}$

Thus, as $20^{\text {th }}$ century began, the prominent figures of the Rusydiah Club who became members of the Rijkraad also known as imperial

19 "Contract met Lingga, Riouw en Onderhen 1 Mei 1905", in Arsip Nasional Republik Indonesia (ANRI), Surat-Surat Perdjandjian, pp. 236-269.

20 Tagliacozzo, "Kettle on a Slow Boil, p. 70-71.

${ }^{21}$ For example, refer to Nationaal Archief Den Haag (NA) verbal, "Confidential letter from the Governor General in Bogor to the Resident of Riau in Tanjung Pinang" (16 March 1904).

22 Also refer to NA verbal, "Copies of (afschrift) confidential letter from the secretary of the Governor General in Bogor to the Resident of Riau in Tanjung Pinang", N0. 522 (19 November 1904).

${ }^{23}$ For example, refer to NA verbal, "Copies of (afschrift) letter from C. Snouk Hurgronje as Adviseur voor Inlandsche en Arabische Zaken to the Governor General of the Dutch East Indies in Bogor", No. 46 (7 May 1904). 
Council or Abl al-Mushawarah (congress consultants) and the royal court of the Riau-Lingga government responded and put up a fight against the politics of the Dutch colonial government. Due to their attitude and activities, a number of Dutch resources also reported this group as the verzets-partij (opposition group) or the Bugis opposition group, with the main figures being, among others, made up of Raja Ali Tengku Kelana also known as Raja Ali Kelana, Raja Hitam or Raja Khalid Hitam, Raja Abdul Rahman Kecik, Raja Muhammad as well as Tengku Besar, the succeeding candidate for the Sultan of RiauLingga. ${ }^{24}$

It can be seen how members from a group of 'Ulama' who were initially focused on producing books and discussing current issues changed to become politicians who fought against colonialism. They initiated an organised, local national movement and anti-colonial fight which critically monitored all political moves made by the Dutch colonial government towards the Riau-Lingga government. They also made various political moves which triggered the anger of the Dutch colonial government. For example, two weeks after Japan's victory over Russia in 1905, a member of the Roesidijah (Club) named Raja Hitam also known as Raja Khalid Hitam had reportedly made a negotiation in Singapore on shifting the government of Riau-Lingga to Japan on the Sultan's name in order to end the political pressure of the Dutch colonial Empire. ${ }^{25}$

Before signing the political contract in 1905, this group would hold meetings to debate on issues regarding the Dutch colonial Empire at the house of Raja Ali Kelana at Bukit Bahjah on Penyengat Island from $7^{\text {th }}$ to $14^{\text {th }}$ February 1904 . During the meeting, three important issues were decided: (1) to reject the new political contract (the 1905 political contract); (2) to instruct Hasan Husin a teacher from Jambi

\footnotetext{
${ }^{24}$ Barbara Watson Andaya, "From Rum to Tokyo: The Search For Anticolonial Allies By The Rullers of Riau, 1899-1914", in Indonesia (24th October 1977), p. 148. Also refer to copy of (Afschrift) confidential letter (geheim) from Resident William Albert de Kanter in Tandjong Pinang to the Governor General of the Dutch East Indies in Batavia, on 29th February 1904. Also refer to, "Rioum en Onderhooriheden" [Riau dan Daerah Takluknya] in Encyclopedia van Nederlansch-Indie. Derde Deel N-Soema. (SGravenhage- Leiden: Martinus Nijhoff - N.V. v/h. E.J. Brill, 1919), pp. 621-622. Information about a group known as Rusydiah Club and its early management, please see Timothy P. Barnard, "Taman Penghiburan: Entertainment and the Riau Elite in the Late 19th Century", in JMBRAS, volume LXVII Part 2 (1994).

25 Andaya, "From Rum to Tokyo, pp. 136-7.
} 
who taught at the house of Raja Ali Kelana to write a letter seeking aid to the Sultan of Turkey, for Riau-Lingga was an Islamic empire; (3) the letter, which was signed by Sultan Abdulrahman, was brought by Muhammad Thahir and Raja Khalid Hitam to Mecca and later delivered to the Sultan of Turkey, for Riau-Lingga was an Islamic empire. ${ }^{26}$

A similar meeting was conducted at the same place when the Dutch colonial government made plans to arrange for government representatives to pay the highest respects to the ambtenar (Dutch officials) who came to visit the provinces of the Lingga-Riau Empire. ${ }^{27}$

The seeds of this resistance began to sprout when chapter three, verse one in the political contract signed on $18^{\text {th }}$ may 1905, which was written in Dutch and Malay, reaffirmed the Riau-Lingga as an achazah or loan from the Dutch colonial government to Sultan Abdulrahman Mu'azzamsyah:

The Lingga Riau sultanate remains to have been handed to the Sri Paduka Tuan Sultan 'Adulrrahman Ma'azhzham Sjah as an achadzah (a loan) with firm recognition from the Sri Paduka Tuan Sultan that he will follow the conditions set in this treaty with full perfection and loyalty. ${ }^{28}$

Looking back into history, before the 1905 political contract was signed, it can be read how 1902, the Riau-Lingga court officials on Penyengat Island had already begun making protests against the Dutch East Indies government by refusing to raise the Dutch flag on the government ship following the change in the protocol of receiving official visits between both governments. This event was reported by A.L. van Hasselt, resident to the Governor General in Batavia who explained that Sultan Abdulrahman was a dissident who was surrounded by the hard-core Royal Council or the Abl al-Mushäwarah.

After that, another episode involving a flag occurred on $1^{\text {st }}$ January 1903, when during an official visit by The Resident of Riau to

\footnotetext{
${ }^{26}$ NA Verbaal, "Confidential letter (geheim) from Resident William Albert de Kanter to the Governor General of the Dutch East Indies in Bogor", No. 21 (29) th $^{\text {February }}$ 1904); Andaya, "From Rum to Tokyo, p. 130.

27 "Catatan Harian Encik Abdullah", YKIS Collection, No. 2.

28 The original versional in the Dutch says: "Het Sultanaat blijft als leen afgestaan aan Sultan Abdoelrachman Maadlam Sjah onder nitdrukkelijke voorwaarde van stipte en trounve nakoming der in dit contract omschreven verplichtingen." See ANRI, Surat-Surat Perdjandjian, pp. 239-240.
} 
Penyengat Island, it was discovered that Sultan Abdul Rahman had not raised the Dutch flag in front of the Kedaton Court House. This resulted in a serious warning from The Resident of Riau, and it was even reported to Governor General Roseboom in Batavia: "He (Sultan Abdul Rahman) acted as a free king and raised his own flag."

Another episode of resistance involving a flag also occurred through the defiance to use the Dutch colonial flag on the Riau-Lingga government ship. This happened on a voyage across the Sambu Island waters by the Penyengat, during which the Dutch flag was not raised as it was supposed to. ${ }^{29}$ The final resistance made towards the regulation of raising the Dutch flag as a sign of the suzerainty of the Dutch on the Riau-Lingga government happened when Resident W.J.Rahder visited Penyengat Island in occasion of marriage ceremony of Sultan Abdulrahman Mu'azamsyah's family member. ${ }^{30}$

\section{The Reactions and Effects on the Dutch Colonial Government}

Some of these 'flag' occurrences were responsible for prompting the Dutch colonial government to formulate a new political contract between the Resident and the Sultan of Riau-Lingga on 18 th May 1905. This included a mention on the regulation for the installation of the Dutch and Riau-Lingga flags in chapter thirteen, verses five, six, seven and eight. For example, it is mentioned in verse seven that the position of the Dutch flag must be higher than that of Riau-Lingga:

Though the Sri Paduka Tuan Sultan may use the white flag to mark his status on land and at sea, with him will the Dutch flag forever remain and it cannot be bigger, and if it is used on land it must be positioned under the Dutch flag and if there are two poles, the pole for the Holland flag must be built taller, while there is no place for fixing the flag of Holland, therefore the Holland flag must be placed in honour on the ship. ${ }^{31}$

The scholars of Riau-Lingga, a majority of whom were court officials as well as advisors to the Sultan were constantly influencing their ruler with the anti-colonial spirit until it slowly began to change

${ }^{29}$ ANRI, Riouw 229. 2. A copy of confidential letter (geheim), Resident of Riau, Wiliam Albert de Kanter to Sultan Abdulrahman Mu'azamsyah, No. 20/G/28, dated 1 March 1904.

${ }^{30}$ ANRI, Riouw 230. 3. A copy of (afschrift) letter, Resident of Riau W.J. Rahder to Sultan Abdulrahman Mu'azamsyah, No. 222/57 dated 18 June 1909.

31 ANRI, Surat-Surat Perdjandjian, p. 249-250. 
his attitude, which was previously prone towards upholding the policies of the Dutch. In the letter of abdication or impeachment of Sultan Abdulrahman Mu'azamsyah and the Tengku Besar of the RiauLingga sultanate, which was read by a Dutch representative in the halls of the Roesidijah Club, the headquarters of the verzets-partij on Penyengat Island, the Resident of Riau, G.F. de Bruynskop scoffed at Raja Ali Kelana and his group, calling them "people with hostile intentions towards the Sri Paduka of the Dutch colonial government." 32

As a result, after signing the political contract on $18^{\text {th }}$ May 1905 (Contract met Lingga, Riouw en Onderhoorigheden - the Political Contract with Lingga, Riau and the districts under its rule) ${ }^{33}$ the relationship between the Dutch government in Tanjung Pinang and the central government of Riau-Lingga on Penyengat Island became unstable. This became increasingly so when the Dutch government proposed a new political contract in 1910 .

The proposition of a new political contract made by the Resident of Riau to Sultan Abdulrahman Mu'azzamsyah became an important issue and topic of discussion in Raja Ali Kelana's group. This group was always comparing the Raja-Lingga government of that particular time too that of the past golden days of glory. They were also always offering their political insights and trying to make Sultan Abdulrahman Mu'azzamsyah realise that he had not only given up too much room but also his dignity to the Dutch colonial government.

The political conflicts and tension between the Riau-Lingga court on Penyengat Island and the central Dutch government in Tanjung Pinang finally reached its climax when Sultan Abdul Rahman Mu'azamsyah, acting on the advice of Raja Ali and his followers, finally refused to sign a new political contract proposed by the Dutch government in 1910. In other words, this group of scholars succeeded in convincing Sultan Abdulrahman that the new treaty or political contract will only further tarnish his dignity and power and that of his government on the provinces under their rule.

The role played by the Riau-Lingga Muslim scholars provided the consideration for the excuses and decisions made by the Dutch East Indies government in Batavia and the Resident of Riau in Tanjung

\footnotetext{
32 Tengku Ahmad Abubakar and Hasan Junus, Sekelumit Kesan Peninggalan Sejarab Riau, (Asmar Ras, 1972), p. 43.

${ }^{33}$ Refer to ANRI, Surat-Surat Perdjandjian, pp. 237-269.
} 
Pinang in formulating a new policy for keeping a direct eye on the court at Riau-Lingga and the districts under its rule. Finally, Sultan Abdulrahman's constant refusal to sign the political contract in 1910 became reason enough for the Dutch government to take political and military action, such as had been suggested by C. Snouck Hungronje to the Governor General of the Dutch East Indies government in 1904.34

The political tension reached its peak on Wednesday, $3^{\text {rd }}$ February 1911. As reported in the Niuwe Rotterdamsche Courant newspaper, which was published in Rotterdam in the Netherlands, ${ }^{35}$ "three steamship: the Koetai, the Java and the Tromp, led by the torpedo hunter Koetai, held a demonstration on the naval combat power of the Dutch East Indies in the Riau waters around Penyengat Island (Drie stoomschepen, de Koetai, de Java, en de Tropm, houden een demonstratie in wateren van Rioun). On the three warships, a group of marechaussee (marsose, a group of elites such as the ones used to end the fight with the people of Acheh in 1903) who would descend on the Island on dozens of lifeboats.

At that time, Sultan Abdulrahman was in Daik, Lingga, and had appointed Raja Abdul Rahman bin Abdullah also known as Raja Abdul Rahman Kecik as his representative on Penyengat Island. Not long after that, the marechaussee soldiers who were already on the island began to surround Kedaton Court, the home of the Tengku Besar, the home of former resident, Kelana Raja Ali Raja Kelana Ali, as well as other places on the island. This gripping new atmosphere became clear when Controller H.N. Veemstra from Tanjung Pinang sent a notification letter to the Resident of Riau, G.F. de Bruinjskop, which among others stated:

In the name of His Highness Governor General of Betawi challenged, therefore the Seri Paduka Government of HindiNetherland strongly think from today Sri Paduka Tuan Sultan Abdulrahman Mu’adzam Syah and Tengku Umar of Riau-Lingga government and its districts, are terminated from his title. The Sultan is terminated from his title because there were so many times he has gone against the political contract; has been advised several times by Sri Paduka Governor General of Betawi and Sri Paduka Tuan Besar, Resident of Tanjung Pinang. As a result of

\footnotetext{
${ }^{34}$ NA verbal, "Copy of letter (afschrift) from C. Snouck Hurgronje to the Governor General of the Dutch East Indies in Bogor", No. 46 (7th May 1904).

35 "Afzetting van de Sultan van Lingga-Riouw En Onerhoorigheden", in Nieuew Rotterdamsche Courant, 68ste Jaargang-No. 42, Zaterdag (11 February 1911).
} 
the Sultan ignoring or breach the agreement and reform of what it should be. And will never breach the political contract again and to write down all order and rule of Sri Paduka Governor and his representatives. And the Sultan wants to implement and arrange together with Governor's Representative, justice ruling in his state. Hence, he broke his promises and go against the rule which is about confronting the use of Holland flag. Hence Tengku Besar was terminated from his title because he follows those who have intention to fight with Sri Paduka Gevernor of Hindi-Netherland and he has incited (hatred) up to his words to ignore the advice of Sri Paduka Governor's Representative. Therefore, the Sultan also together followed those who have bad intention. ${ }^{36}$

In order to realise this decision, the Resident of Riau, G.F. de Brujnskop, gave directions to the Controller of Tanjung Pinang, H.N. Veemstra to depart for Lingga to inform Sultan Abdulrahman. When he arrived in the waters of Belakang Daik, the Resident went to meet Sultan Abdulrahman's ship and delivered a letter encased in a yellow envelope.

When Sultan Abdulrahman arrived on Penyengat Island, the Resident of Riau and a number of Dutch government officials from Tanjung Pinang, as well as the council members of the Riau-Lingga government were waiting at the Roesidijah (Club) building, where the

36 The original version in Malay language says:

"Dengan nama Jang Dipertuan Besar Governeur General Betawi dichabarkan Maka adalah Seri Paduka Governement Hindia Nederland menimbang fardu ini bari juga Sri Padoeka Tuan Sultan Abdulrahman Mu'adzam Syah dan Tengku Umar (Tengku Besar) Kerajaan Riau Lingga serta daerah takluknya diberbentikan dari pada pangkatnya itu. Maka tuan Sultan diberbentikan dari pangkatnya itu sebab banjak kali melanggar Politik Contract; beberapa kali djuga diberi nasehat oleh Sri Paduka Governeur Generaal Betawi dan Sri Padoeka Toean Besar Resident Tanjoeng Pinang. Maka itu dengan tiada Tuan Sultan mengindahkean atau mengingatkan perdjandjian yang akan mengubabkan apa-apa jang tiada patut itu. Dan tiada sekali-kali akan melanggar Polotik Contract lagi dan mesurat segala perintah dan aturan Sri Padoeka Governeur dan wakilnya. Dan djuga Tuan Sultan bendak menjalankan dan mengaturkan bersama-sama Wakil Governeur pemerintah yang adil dalam negerinya. Maka mungkirlah ia didalam perjanjiannya dan juga melanggar aturan yang menentang pasal memakai Bendera Holanda. Maka Tengku Besar diberhentikan dari pangkatnya itu disebabnya sekali ianya mengikutkan orang yang berniat bemusuban dengan Sri Padoeka Governeur Hindia Nederland dan ialah membujuk (menghasut) sampai anjurannya tidak menghindabkan sekalian nasehat Wakil Sri Padoeka Governeur itu. Maka itu Tua Sultan juga sama sekali mengikutkan orang yang berniat kejahatan itu."

See, Abubakar and Junus, Sekelumit Kesan Peninggalan Sejarah Riau. 
headquarters of the verzetparty was situated. It was there that the besluit (letter of decree) from the Governor General of the Dutch East Indies government on the abdication or impeachment of Sultan Abdul Rahman Mu'azamasyah and Tengku Besar Umar was read, based on the Governor General's besluit dated 10th February 1911.

A letter from the Resident of Riau, G.F. Bruijnskop to Sultan Abdulrahman Mu'azzamsyah on $9^{\text {th }}$ February 1911, which is now kept in the Tropen Museum, Amsterdam, contained the following explanations:

After all, we would like to inform that with the decision made that His Highness Governer Hindi-Netherland on the $3^{\text {rd }}$ February 1911 no. 1, Sri Paduka our friend has been terminated from the title of Sultan Lingga Riau and its provinces because Sri Paduka our friend breached political contract. And Tengku Besar also terminated. Therefore now we are acting the ruling of Lingga Riau Government and its provinces. This is according to article 4 of political contract 1905. This news we inform you Tengku Besar today. Therefore if Sri Paduka our friend would like to know or would like further explanation, please Sri Paduka our friend comes to our office in Tanjung Pinang. ${ }^{37}$

A number of oral sources on Penyengat Island stated that a fight ensued from the side of the Riau-Lingga court on the island. However, what is certain is that on a Saturday night, Sultan Abdulrahman Mu'azzamsyah, together with the Tengku Ampuan, his Queen, Raja Ali Kelana, Raja Khalid Hitam and their relatives left the island on a ship

${ }^{37}$ The original version in Malay language says:

"Wabakdu adalah kita maklumkan bahawa dengan besluit ini sri paduka yang dipertuan besar gubernur Hindia Nederland tertanggal 3 Februari tabun 1911 angka 1 sri paduka sababat kita telah berhentikan daripada pangkat Sultan Lingga Riau dan da'irah takluknya oleh karena sri paduka sababat kita ingkar akan politik. kontrak. Dan Tengku Besar diberhentikan juga. Maka sekarang ini kita yang memangku pemerintahan kerajaan Lingga Riau dan da'irah takluknya. Yaitu menurut ayat 4 daripada politik kontrak tabun 1905. Dari bal ini kita telab beritabukan kepada Tengku Besar pada ini hari. Maka jikealau Sri Paduka sahabat kita hendak mengetahui atau hendak mendapat terang lagi boleh lah Sri Paduka sahabat kita datang ke kantor kita di Tanjung Pinang adanya."

A letter from the Resident of Riouw G.F. de Bruynskops to Sultan Abdulrahman Mu'azzamsyah written in Tanjungpinang on $9^{\text {th }}$ February 1911. Tropen Museum (TM) Number: 12121 -a. 
captained by Niggal also known as Wak Senang, heading towards Singapore and Johore.

Thus, it was two years later that the reign of the Riau-Lingga government and the districts under its rule ended, with the signing of a beluit on the elimination of the aforementioned government by the Governor General of the Dutch East Indies in 1913. This was later included in the Stadblad (state documents). From that moment the Riau-Lingga government was eliminated, and the districts under its rule fell under the direct control of the Dutch East Indies. However, some exiled members of the verzets-partij, such as Raja Khalid Hitam and Raja Ali Kelana continued to seek for anti-colonial allies in Singapore and Johore until the late $1913 \mathrm{~s} .{ }^{38}$

\section{Conclusion}

The 'Ulama' of Riau-Lingga played a pivotal role in considering the excuses and decisions made by the Dutch colonial government in Batavia and The Resident of Riau in Tanjung Pinang in the move to the application of a new policy in overseeing the Riau-Lingga court and the districts under its rule. In addition, the 'Ulamä' also gave their political views and helped Sultan Abdulrahman Mu'azzamsyah to realise that he should no longer provide space nor sacrifice his honour to the Dutch colonial government. They also acted as advisors to the Sultan, while influencing him with the anti-colonial spirit, which slowly began to change the attitude of Sultan Mu'azzam Syah from being prone towards supporting the Dutch colonial policies to finally rejecting them. In sum, the activism of the 'Ulama' of Riau-Lingga in the Dutch colonial period (1900-1913) suggested the close connection of Islam in Indonesia and the Malay world. []

\section{References}

\section{Books and Articles}

Reid, Anthony. Asal Mula Konflik Aceb Dari Perebutan Pantai Timur Sumatera hingga akbir Kerajaan Aceh abad ke-19. Trans. Masri Maris. Jakarta: Yayasan Obor Indonesia, 2005.

Arsip Nasional Republik Indonesia (ANRI). Besluit Governor General of Dutch East Indies, No. 8. 16 January 1897.

\footnotetext{
${ }^{38}$ For further information, refer to Andaya, "From Rum to Tokyo, pp. 148-154.
} 
Arsip Nasional Republik Indonesia (ANRI). Surat-Surat Perdjandjian Antara Kesultanan Riau dengan Pemerintahan V.O.C. dan Hindia Belanda 1785-1809. Jakarta, 1970.

Andaya, Barbara Watson. "From Rome to Tokyo: The Search For Anticolonial Allies By The Rulers of Riau, 1899-1914." in Indonesia, 24 October 1977.

Barnard, Timothy P. "Local heroes and national consciousness: The politics of historiography in Riau." Bijdragen tot de Taal-, Land-en Volkenkunde 4de Afl (1997).

E. Nescher. De Nederlanders in Djohor en Siak 1602 tot 1865 Historische Berschrijving. Batavia: Bruining \& Wijt, 1870.

Locher-Scholten, Elsbeth. Kesultanan Sumatera dan Negara Kolonial Hubungan Jambi-Batavia (1830-1907) dan Bangkitnya Imperialisme Belanda. Jakarta: KITLV and Banana, 2008.

Tagliacozzo, Eric. "Kettle on a Slow Boil: Batavia's Threat Perceptions in the Indies' Outer Islands, 1870-1910." in Journal of Southeast Asian Studies, 31, 1 (March 2000).

Hussin, Nordin. "Trading Networks of Malay Merchants and Traders in the Straits of Melaka from 1780 to 1830." Asian Journal of Social Science 40, no. 1 (2012).

Muttalib, Jang A. "Suatu Tinjauan Mengenai Beberepa Gerakan Sosial di Jambi Pada Perempat Pertama abad ke-20." in PRISMA, No. 8 (1980).

Bongenaar, Karel E.M. De ontwikekeling van het zelfbestuurrend landschap in Nederlandsch Indie 1855-1942. Zitphen: Walburg Pers, 2005.

Andaya, Leonard Y. Kerajaan Johor 1641-1728 Pembangunan Ekonomi dan Politik. Kuala Lumpur: Dewan Bahasa dan Pustaka, 1987.

Winstedt, R.O. A History of Johore (1365-1895). Kuala Lumpur: JMBRAS, 1979.

Vos, Renout. Gentle Janus, merchant prince The VOC and the tightrope of diplomacy in the Malay world, 1740-1800. Leiden: KITLV Press, 1993.

Abdullah, Taufik. "Reaksi Terhadap Perluasan Kuasa Kolonial: Jambi Dalam Perbandingan." in PRISMA, No. 11 (1984). 
Abubakar, Tengku Ahmad and Hasan Junus. Sekelumit Kesan Peninggalan Sejarah Riau. Asmar Ras, 1972.

Sinar, Tengku Lukman. "Perang Besar dalam Kampung Kecil, Riwayat Perjuangan Rakyat Sunggal.” in PRISMA, No. 11 (1984).

Barnard, Timothy P. "Taman Penghiburan: Enteirtainment and the Riau Elite in the Late 19th Century." in JMBR AS, volume LXVII, part 2, 1994.

Matheson, Virginia. "Strategies of Survival: The Malay Royal Line of Lingga-Riau." Journal of Southeast Asian Studies 17, no. 1 (1986). 